\title{
MAKING SENSE OF PSYCHOANALYSIS IN CRIMINOLOGICAL THEORY AND PROBATION PRACTICE
}

\section{David Smith}

Professor of Criminology

Department of Applied Social Science

Lancaster University

County College South

Bailrigg

Lancaster

LA1 4YD

Email: d.b.smith@lancs.ac.uk

\section{Biographical note}

David Smith has been at Lancaster University for 30 years, originally as Lecturer in Social Work, and since 2002 as Professor of Criminology. His first contribution to the Probation Journal, written while he was a probation officer, appeared in 1976. 


\begin{abstract}
Recent developments in criminology have included a revival of interest in offenders' biographies and inner emotional experiences, and a stress on the importance of selfunderstanding for an understanding of crime. These approaches recall discussions of probation practice from the 1950 to the early 1970s, in which writers sought to make sense of the psychoanalytic emphasis of social work training. The paper discusses the most striking of these efforts, by Clare Winnicott and William Jordan, and explores their relevance to current thinking and research on probation, in which the importance of the relationship between offender and supervising officer is once again receiving close attention.
\end{abstract}

Keywords psychoanalysis, insight, emotions, client-worker relationship, desistance 


\section{MAKING SENSE OF PSYCHOANALYSIS IN CRIMINOLOGICAL THEORY AND PROBATION PRACTICE}

One of the most striking developments in recent criminology is the revival of attention to the individual biographies of people who offend, to their inner, sometimes unconscious, experiences, and to the importance of emotion as source of action. This development has coincided with a very different tendency in probation policy and practice, that stresses the rational, cognitive elements in offending and the need for practitioners to give priority to the careful, actuarial assessment and management of risk. While the relationship between criminology as an academic discipline and probation policy and practice has varied over the past fifty years, it would be strange to argue that some relationship should not exist, or that the probation service has nothing to learn from criminology, or criminology from probation practice. The purpose of this paper is firstly to argue that some recent trends in criminology recall approaches to understanding offending and working with offenders that characterised the practice of probation officers in (roughly) the third quarter of the twentieth century. These approaches were much criticised by the most influential criminologists of the 1960s and 1970s, and - partly as a result - were largely abandoned as a basis for practice. Now that they are being revived within criminology (usually without acknowledgement of their resemblance to a formerly disparaged approach to the understanding of offenders), it may be useful to consider their implications for practice, and how they connect with the emerging sense within probation theory and research that the quality of the immediate relationship between officer and offender may be a crucial factor in the success or failure of interventions.

\section{Recent criminology and the revival of complex subjectivity}

In the first issue of the now well established and successful journal Theoretical Criminology, the veteran Norwegian criminologist Nils Christie (1997) described 'four blocks against insight' which he attributed to the over-socialisation of social scientists and their consequent lack of access to their own personal experiences. He argued that this produced a paradoxical lack of understanding in a field of which we all have immediate experience:

We have sinned and been sinned against, we have acted as law-breakers, as police, as prosecutors, as defenders, as prison guards...We...strive to control ourselves or others or to protect ourselves or others from still other people's attempt to control us. We are all continuously torn between lust and loyalties, confronted with dilemmas, often ending up with regrets for our failures. There is so little in the field of criminology that we have not yet experienced.

The problem is access to ourselves. Access, and respect for what we find (Christie, 1997: 14-15).

Both within criminology, as in Hal Pepinsky's (1995) advocacy of a 'peacemaking' as opposed to a war-making criminology, and in wider social theory, as in the later work of Anthony Giddens (1994), one can find echoes of Christie's position. The stress of these writers on the importance of self-understanding as a basis for understanding others would have been entirely familiar to probation officers trained in the 
psychoanalytically influenced environment of the 1950s and 1960s (Vanstone, 2004: 105); but it is a stress entirely at odds with the emphasis on behavioural 'competencies' which dominated social work training from the early 1990s, and with the increasing tendency in probation training to define good practice solely in terms of adherence to organisational procedures and national standards. I will return later in the paper to the practical sense that could be (and has been) made of insight into oneself in the context of probation practice.

This stress on self-understanding is one aspect of a more general tendency in recent criminology to reinstate the importance of understanding the complexity of individual experience and motivation in theorising about offending. There are several interlinked sources of this renewed interest in individual-level explanations. Among these are a revival of interest in psychoanalytic theory and its sense of a fractured, unstable, 'postmodern' identity (particularly masculine identity) (e.g. Jefferson, 1994; 2002a); analysis of the importance of self-concept and autobiographical narrative in understanding desistance from offending (e.g. Maruna, 2000; Maruna et al., 2004); the stress on relationships and their importance for deviance or conformity characteristic of the work of Braithwaite (1989) and Sampson and Laub (1993); and a revival of interest in emotions rather than rational, cognitive processes as sources of action (e.g. Katz, 1988; Scheff, 1994, 1997). Gadd and Farrall (2004) provide an example of work that uses individual case studies of a kind that used to be familiar to probation officers to understand processes of desistance in the light of theories of narrative, masculinity, and unconscious mechanisms of defence. The authors conclude:

The latent or unconscious meanings embedded in offenders' narratives are as important as the actual words, narratives or discourses used. These unconscious meanings can only be 'got at' through in-depth interpretive work (Gadd and Farrall, 2004: 148).

For the late John Hood-Williams, too, in his discussion of Jefferson's advocacy of a 'psychosocial' approach in criminology, an understanding of the nature of masculinity requires criminologists to return to the insights of psychoanalysis, long neglected by a sociologically oriented criminology: 'since there seems to be no ready alternative discourse to psychoanalysis that can offer an account of human subjects it [the approach to masculinity of Jefferson and others] also means that criminology must find itself engaging in debates that only a few years ago would have seemed desperately obscure' (Hood-Williams, 2001: 54). And, one might add, desperately old-fashioned, if participants in these debates were aware of the legacy of psychoanalytical criminology (e.g. Friedlander, 1947; Glover, 1960) and of psychoanalytic ideas developed in different contexts but subsequently influential on probation thinking (e.g. Winnicott, 1958; Institue of Marital Studies, 1962; Pincus, 1973 [originally published in 1962]). Despite their mandatory deployment of poststructuralist terms like 'discourse' and 'narrative', there is little in recent psychoanalytically-oriented accounts with which serious-minded probation officers of the 1960s would not have felt at home. 


\section{The 'treatment model' in practice}

In the discussion so far I have tried to avoid asserting that the probation officers of that generation in fact used some adaptation of psychoanalytic theory in their routine practice. Though there is no doubt that they were exposed to psychoanalytic ideas in their initial and subsequent training, it is far less clear that these ideas were widely found to be useful as a basis for practice (Vanstone, 2004). It is tempting but potentially misleading to assume that ideas imparted in training were translated into practice in a straightforward way, or that contemporary writing about probation practice gives a reliable account of what that practice was actually like. Awareness of this has led some commentators to suggest that the 'treatment model' which Bottoms and McWilliams (1979) proposed to replace with their 'non-treatment paradigm' existed more in the minds of probation trainers and commentators than in the world of everyday practice (Raynor and Robinson, 2005). Certainly it is possible to overstate the dominance of a single, psychoanalytical model of offending and of probation intervention. Vanstone's (2004) reading of the Probation Journal of the period shows that while psychoanalytically influenced accounts appeared they did not go unchallenged, and his interviewees repeatedly suggested that it was a struggle to make sense of such ideas when faced with the practical realities of everyday supervision ${ }^{1}$. Officers' typical reaction was to develop 'folk theories' based on their experiences of practice, in which psychoanalytic concepts were domesticated to make them manageable in the probation context (Vanstone, 2004: 114-19). Even in the perhaps more rarefied Case Conference, while articles on probation topics were not uncommon, they tended, with a few notable exceptions, to avoid overtly psychoanalytic accounts and interpretations. But in this they resembled articles on other topics: psychoanalytic approaches to social work were evidently regarded with some suspicion as an American import (e.g. McWhinnie, 1956: $21^{2}$ ).

\section{Casework and agency function}

Probably the most common theme of Case Conference papers on probation was whether 'casework' was possible given the probation officer's legal authority over the client. By the late 1950s most contributors took the view that it was, sometimes relying on an analogy between supervision and good parenting (Newton, 1958). Waldron (1957: 159), for example, argued that some dependency on the part of the client was inevitable in casework, and that with the development of the service the probation officer had come to use casework methods, 'at the same time exploding the belief, which was regarded as a principle, that a client had to come voluntarily in order to benefit from casework help ${ }^{3}$. The most original, and eventually famous - or notorious - paper on this theme was from Clare Winnicott (1962), the social worker

\footnotetext{
${ }^{1}$ Two of the psychoanalytically based articles cited by Vanstone were by Geoffrey Parkinson, a probation officer who a few years later became a well-known and outspoken critic of psychoanalytically oriented casework, and was a regular columnist (as 'Tostig' and later as 'Tailgunner Parkinson') in the magazine New Society, until it ceased publication in 1987.

${ }^{2}$ In a review article, 'Out of wedlock', she says of the book under review that the 'interpretation here is based on psycho-analytic theory, and as such will certainly be provoking to many British social workers'.

${ }^{3}$ At the time, of course, offenders on probation, though not those on most forms of after-care, had formally consented to their supervision. Foren and Bailey (1968) were later to argue that if authority was a problem for casework this applied to settings other than probation (see Raynor and Robinson (2005: 58).
} 
wife of the psychoanalyst D.W. Winnicott, and this took an uncompromisingly psychoanalytic line. Following in part the argument of her husband in a paper on 'The anti-social tendency' originally read in 1956 (Winnicott, 1958: 306-15), she argued that the element of authority in the relationship, far from being a handicap, was essential to its success. She asked:

...are there not theories which teach us that the delinquent is unconsciously looking for just this, for a human being to become a respected and controlling authority, because this is what he has been deprived of in his family relationships? (Winnicott, 1962: 181).

Like her husband, she argued that the anti-social tendency expressed an element of hope, 'and repeats an urge (mainly unconscious) to reinstate what is lost'. So:

When a child or an adult commits an offence... he brings into action the machinery of the law. The probation officer who is then asked to do casework with the client feels he ought to apply techniques implying the casework principle of self-determination, but he loses everything if he forgets his relationship to his agency and the court, since symptoms of this kind of illness are unconsciously designed to bring authority into the picture. The probation officer can humanise the machinery of the law but he cannot sidestep it without missing the whole point of the symptom and the needs of the client. If he does miss the point the client either gives up hope or commits another offence to ensure the re-instatement of legal machinery (Winnicott, 1962: 1812).

She makes clear that while sociological factors 'have a bearing' on delinquency, these are in her view secondary to the complex unconscious motivation and needs that she describes. The reason that enforced relationships can work, despite what she sees as the received wisdom of casework that they cannot, is that they meet the delinquent's unconscious need for a relationship with 'a human being who is the embodiment of the legal machinery of society's reaction to him...with whom he can gradually come to terms'. There is 'something deep down in the delinquent that comes to meet the probation officer', and this is why probation works, often better than psychiatric approaches (Winnicott, 1962: 182).

Winnicott's delinquent was as fully equipped with an unconscious mind as the offenders whose case histories are discussed by Gadd and Farrall (2004), but her prescriptions for action on the part of the supervising officer do not include an interpretive leap into the hidden depths of the Id. Instead her principal recommendation is that the probation officer should remain clear about his or her responsibilities as a representative of an agency that is part of the criminal justice system $^{4}$. Put this way, her ideas about the justification for the use of authority by the probation officer seem less dated, even if there remains something indefensibly confident about her ascription to the offender of unconscious motives. It was, however, this latter aspect of her paper that attracted most attention, first favourable

\footnotetext{
${ }^{4}$ I am grateful to my former colleague Alan Cohen for alerting me, many years ago, to the importance of this aspect of Winnicott's paper.
} 
and then dismissive. Hunt (1964), for example, cited Winnicott's paper in arguing (in a style that repeatedly suggests that he had not completely clarified his ideas for himself, let alone for his readers ${ }^{5}$ ) that enforcement of court orders was in clients' interests, though, by virtue of their immaturity, they would not appreciate this; appreciation that it had been in their interests all along would come with greater maturity (see Raynor and Robinson (2005: 57-8) for a satirical but not unfair summary of Hunt's argument). There is no doubt that Winnicott's assumption that offending is a symptom of some kind of illness, if applied with sufficient unselfcritical confidence, could lead to a grotesque denial of the reality of clients' accounts of their problems and experiences. But it seems unlikely that it ever was generally applied in such a way in the probation service: the accounts of this kind of approach in action are more often about relatively specialised voluntary sector agencies, such as the Family Welfare Association (Mayer and Timms, 1970). It was this organisation that Parkinson (1970: 220-21) had in mind when he wrote: 'Clients tried to talk about the gas bill, workers tried to talk about the client's mother. Perceptive clients got the gas bill paid by talking about mother ${ }^{\prime}$.

The complaint here is that psychoanalytically oriented casework is ineffective because irrelevant, and this was a main theme of the critique of social work that emerged in the mid to late 1960s from a newly critical sociology of deviance, influenced in varying degrees by the labelling perspective and by Marxism (for example, Becker, 1963; Matza, 1964). The influence of sociology (which only became a widely accessible discipline at undergraduate level in Britain in the late 1960s) was, as Raynor and Robinson (2005: 70) note, helpful for many social workers and probation officers, in making them more aware of the policy context of their work with individuals and of the potentially damaging effect of stigmatising official labels. The problem was that sociological explanations were often advanced as replacements of rather than complements to more established accounts based on individual biographies or family interactions, presenting social workers and probation officers with an either/or choice, rather than the 'psychosocial' blend advocated much later by Jefferson (2002a). On a note of personal reminiscence, the sociological critique gave me an answer to one of my supervisors of the early 1970s, who argued that young men's tendency to commit domestic burglaries could be understood in terms of their need to break through sexually symbolic barriers: the obvious response was that it was unclear why such Oedipal passions should be common on poor council estates and almost unknown on affluent private ones. Later work, some of it psychoanalytically based, on hegemonic and subordinated masculinities (e.g. Jefferson, 2002b; Messerschmidt, 1993) could provide the outline of an answer to this argument, but at the time none was forthcoming. The problem with this sociological line of explanation, of course, was that its prescriptions for practical action of a kind available to probation officers were not transparent: if criminal behaviour arose from economic inequality and social deprivation, the solution could only lie in political action to promote social and economic justice, to which probation officers'

\footnotetext{
${ }^{5}$ The paper is often unintentionally obscure, and (Hunt, 1964: 243) misleadingly cites 'Melitta Schmideberg, with her psycho-analytic experience and orientation'. This is misleading because Schmideberg was by this time an outspoken critic of psychoanalysis as a basis for casework or anything else. But she was the daughter of Melanie Klein, and in that sense certainly had a psychoanalytic background.

${ }^{6}$ Cohen (1972: 42-44) provides an extended example of this kind of exchange.
} 
contribution could at best be only modest (see, for example, Drakeford and Vanstone (1996) for some later attempts to state what it might be).

\section{Client-probation officer transactions}

Hunt (1964) was unusual among writers of the 1960s in citing Winnicott (1962) in a discussion of the relationship between helping and the use of authority in probation; even Foren and Bailey (1968) made only passing reference to her paper, and subsequent articles in Case Conference (Caudell, 1964; Rees and Burke, 1966) that adopted a position on agency function not unlike Winnicott's do not acknowledge her work. Neither does the author who made what is to my mind the most original and persuasive connections between psychoanalytic writings on casework and practice in the probation setting - Bill Jordan, whose early work, as W.J.O. Jordan and then William Jordan, involved close attention to interactions between client and worker, and in particular to the emotional content of their relationship ${ }^{7}$. Insight into oneself and one's feelings, as recommended by Christie (1997), was central to Jordan's approach. He outlined his ideas in two Case Conference articles (Jordan, 1968a; 1968b) before developing them at greater length in two books in the 'Library of Social Work’ series (Jordan, 1970; 1972).

Jordan's two main explicit influences, apart from his own experiences of practice, were the psychoanalytic work of the Family Discussion Bureau, later the Institute of Marital Studies, at the Tavistock Institute of Human Relations, and the more 'systemic' approach to family therapy represented at the time by Ackerman (1966) and Satir (1967). Another influence was the work on family interaction of R.D. Laing and his associates in the 'anti-psychiatry' movement (e.g. Laing, 1965; Laing and Esterson, 1964), of which more below. Jordan's approach to each of these sources, which he had obviously studied carefully, was to state where his views, developed from his practice experiences, differed from the dominant account - a method that seems exemplary as a means of making sense in a different context of ideas developed in a particular therapeutic setting. The first Case Conference article (Jordan, 1968a: 470-1) argued that probation officers often failed to challenge clients' accounts of their and their families' problems because of their fear that clients would be unable to use insights into the emotional origins and consequences of their actions. Jordan wrote of his own fear that the result of any challenge to the client's account might be murder or suicide, and suggests that if such melodramatic terrors are felt by the worker this is likely to be 'a reflection of the client's feelings'; if the worker has apparently irrational fears this may be because these are what the client is communicating. The paper also introduced the idea of 'centrifugal' families, which was to be developed in Jordan (1972), characterised by intense peer-group involvement on the part of teenage children and a tendency, actual or threatened, on the part of the parents to flee from the emotional pressures of family interaction. This, the typical pattern, according to Jordan, in families of delinquents, is unlike that described in the work of family therapists, and opposite to the 'integrative' pattern described by Laing and Esterson (1964) as typical of the families of young women diagnosed as schizophrenic.

\footnotetext{
${ }^{7}$ Later Jordan went on to address major themes of political economy, welfare and social justice, among others, while never completely cutting himself off from his roots in probation practice.
} 
The second article (Jordan, 1968b) anticipated the arguments of his first book (Jordan, 1970), and more explicitly confronted his dissatisfaction with the theories and descriptions of family interaction to be found in the work of writers associated with the Institute of Marital Studies. Compared with classical psychoanalysis, the work of the Institute was less concerned with internal personality structure and more with the unconscious emotional content of interpersonal action and communication, reflecting the influence of D.W. Winnicott and other theorists who placed a central emphasis on the importance of 'object relations' for emotional growth. The ideas of Anna Freud (1937) were particularly influential (e.g. Guthrie and Mattinson, 1971), with their stress on the ego's unconscious defences against anxiety, including repression, denial, splitting, projection, introjection and projective identification. Jordan (1968b: 299) developed this relational focus, arguing for a less static and internal and more interactive and dynamic view of the unconscious than in classic psychoanalytic theory, and for attention to be paid to 'processes of interaction... between what is unconscious in one person and conscious in another'. The interaction between family members, for Jordan, was often more important than the personality structure of the individuals involved. 'Furthermore, methods of casework which deal with family interaction may be involving unconscious material to a much greater extent than has been suggested' (Jordan, 1968b: 301).

\section{In Client-Worker Transactions (1970) and The Social Worker in Family} Situations (1972) Jordan took these ideas further. First, he stressed that the social worker is unlikely to be able to maintain the detached, analytical role prescribed in traditional writing about casework and family therapy. The traditional approach is 'like describing the game of cricket purely from the bowler's point of view' (Jordan, 1970: 46) ${ }^{8}$, and accounts of family therapy are characterised by 'a certain beguiling simplicity, almost amounting to naivety, in some...descriptions of the therapist's role' (Jordan, 1972: 7). Jordan reminds us that batsmen not only try to make it difficult for bowlers to get them out but also want to score runs off them; that is, the client as well as the worker 'has aims and plans and things he is trying to do' (Jordan, 1970: 45), and these may include getting the worker to carry feelings that the client finds unbearable. The second main point of Jordan's divergence from the established approach of psychoanalytic writing on casework is that he suggests we should think in terms of emotional 'transactions' rather than of projection. In the classic account, what is projected is unconscious phantasy material; in Jordan's account, the 'transaction' comes about as a result of a 'defensive manoeuvre' by the client, and what is unconsciously transmitted from client to worker are feelings that the client finds intolerable, unmanageable or too uncomfortable to allow into consciousness. The worker rather than the marital partner or another family member (as in the Institute of Marital Studies version) becomes the recipient of these unconsciously communicated emotions, and a good indication that this has happened is that the worker begins to feel and behave in unaccustomed and exaggerated ways, for example by being 'very angry or very frightened, very protective or very rejecting' (Jordan, 1970: 46).

Thirdly, and here the argument returns to the issues about agency function raised by Winnicott (1962), Jordan diverges from what he sees as the accepted theory in arguing that the emotional content of the relationship between client and worker is

\footnotetext{
${ }^{8}$ Jordan was himself an accomplished cricketer, specialising in spin bowling.
} 
not (as in the psychoanalytic model) made up of unconscious infantile desires and conflicts, and quite distinct from the supposedly adult and rational seeking of help with a social problem; instead it is embedded 'within the social problem presented and the manner of its presentation'. This is because 'a social work agency invites people to express themselves to it in the form of a social problem'; that is, agency function shapes the way the problem is presented, and this means among other things that the differences between social workers and psychoanalysts are greater than the differences between their respective clients (Jordan, 1970: 5-6). The case discussions Jordan gives later in this book and in his later work generally show workers behaving in a firm, even directive, manner, as one would expect from his stress on the importance of the fact that the social worker - who in Jordan's early work is always a probation officer - works within an agency context that represents a set of social expectations and requirements. Once workers have understood what part of what they are feeling comes from clients' transmission of unmanageable emotions, they can and should begin behaving in a way that reflects the agency's priorities and social purposes.

The psychoanalytic perspectives of the Institute of Marital Studies and related work were thus radically reworked by Jordan, but it remains true that these perspectives provided the starting-point for his understanding both of family interactions and of what goes on in the relationship between worker and client. The same debt to psychoanalysis remains in the work of the 'anti-psychiatrists' Laing, Cooper and Esterson, whose influence appears particularly in Jordan's second book (Jordan, 1972). Given the fame Laing and his colleagues achieved in counter-cultural circles in the second half of the 1960s, it is perhaps surprising that relatively little trace of their work is to be found in writing specifically on social work, then or later. Their claim that 'madness', and schizophrenia in particular, could be understood and made intelligible through a careful analysis of patterns of family interaction and communication, created space for a social rather than a medical approach to treatment, and thus possibilities for social work intervention. In practice, what Jordan and others took from 'anti-psychiatry' was very much what they also took from more orthodox psychoanalytic approaches: a sense of the need for close attention to patterns of communication in families, to what went unsaid as well as what was said, and to the impact of intervention on the worker's feelings and responses. Apart from this, the influence of the 'anti-psychiatrists' was probably felt most in the field of family therapy, because of the overlap between their thinking and that of family systems theorists and therapists (e.g. Walrond-Skinner, 1976). The more opaque philosophical pronouncements of Laing and his colleagues, typically a mixture of psychoanalysis, Hegelianism, Marxism, existentialism and mysticism, remained inaccessible to all but a few co-believers ${ }^{9}$.

\footnotetext{
${ }^{9}$ Sigal (2005a: 31), who was closely associated with Laing, Cooper and Esterson in the early 1960s, gives this example (among others) in his funny and moving novel based on this experience: 'Within a micro-social nexus the holistic hungers of the community members dialectically reinforce my narcissistic violence, but produce a negation of a negation in which we abduct one another from our arbitrary roles. Thus a wholly new politics emerges: an anti-imperialism of the mind'. This is the lightly fictionalised David Cooper, speaking of Villa 21, his experiment in democratic psychiatry. According to Sigal (2005a: 34), he spoke more plainly when he had been drinking, describing Villa 21 as 'the last chance for some of those kids. Maybe I can help a few make it.' Sigal (2005b) quotes a therapist who believed (in 2005) that Laing and his colleagues had brought about only cosmetic changes in the psychiatric system, in the direction of greater humanity and respect for patients, but that there are still 'Laing- and Esterson-influenced doctors, probation officers, psychologists, who are out
} 


\section{Back to the 1960s?}

So far I have tried to identify some possible virtues in the practice (or at least the practice that was written about) of the probation officers of the 1960s and early 1970s, and to show how themes that appear in their writing are similar to those identified as important in some recent criminological work. But nostalgia would be an unreliable basis on which to establish preferences for policy and practice, and it needs to be acknowledged that the efforts of these probation officers led to (among other things) the IMPACT report (Folkard et al., 1976) and the famous overall conclusion that, when it comes to interventions intended to make offenders less likely to go on offending, 'nothing works' (Martinson, 1974). This is not the place to repeat a story that is now well known (and well summarised recently in Raynor and Robinson (2005)), but even when all due qualifications have been made about Martinson's conclusion, about the methodological problems inherent in the IMPACT experiment, and about the existence of contradictory, more encouraging, findings (Shaw, 1974), the conclusion is inescapable that psychoanalytically oriented casework was unable to show that (in general) it 'worked' in the sense of helping its clients to become less prone to commit offences. Any claim, therefore, that we might have something to learn from those who practised it needs to be made with due caution and modesty ${ }^{10}$.

If the rediscovery of psychoanalysis by criminologists reflects a justified sense that there were important gaps in the sociological explanations that dominated the discipline for almost forty years, a reasonable conclusion on the failures of psychoanalytically oriented casework in probation might be that it was the techniques and processes of intervention, rather than psychoanalytic theory itself, that were the problem (Keat, 1981). To put the point simply and concretely, not everyone could (or can) practise with the intensity, commitment and sensitivity of a William Jordan, or so subtly adapt psychoanalytic concepts to the probation context. There remains something heroic and admirably democratic about the efforts of pioneering social workers to derive from psychoanalytic theory forms of practice that were feasible in poor neighbourhoods and potentially helpful to deprived, marginalised people (Martinez-Brawley and Zorita, 1998), but there also remains a question about how far they succeeded. So the potentially helpful messages from the probation practices discussed here do not include a recommendation that officers should attempt to turn offenders into subjects for psychoanalysis. Instead, they might be summarised as follows: attend closely to what clients say, how they say it, and what they do not say; be aware of the emotional as well as the rational, cognitive content of communication; be sensitive to the emotional effects clients have on you, the worker (because your relationship with the client may be shaped by feelings of which neither of you is fully aware); try to see clients in the context of their relationships, past as well as present;

\footnotetext{
there working, quietly, in the field'. Laing's enthusiasm for the mind-enhancing qualities of LSD is a central theme of Sigal (2005a), but for obvious reasons this aspect of his practice never had any official influence on social work. An interesting exception is 'Lady Almoner' (1960), who took LSD (then still used therapeutically) while working in a psychiatric hospital. She seems to have had a good time, and afterwards minded less when she was taken for a patient. Her article provoked no comment in the pages of Case Conference.

${ }^{10}$ There are also, of course, important contextual differences between the 1960s and the present, of which the most obvious is probably the increase in the availability of hard drugs and in their use by known offenders (Bennett, 2000). But the probation service had its origins in concerns about substance misuse (Vanstone, 2004), so the link between offending and unwise or compulsive consumption is not a new problem for practitioners.
} 
have respect for the complexity and ambiguity of clients' emotions, just as you have respect for the complexity and ambiguity of your own emotions, and the emotions of those who are close to you; and remain aware that emotions, which may be unconscious or unacknowledged, can be as important in shaping action as conscious, rational thinking.

\section{Conclusions}

As suggested at the start of this paper, these recommendations, derived from writing of the past, are compatible with much more recent trends in criminology. Some of this recent work is explicitly psychoanalytical in inspiration (Gadd and Farrall, 2004; Jefferson, 2002b), and some draws on different traditions in social science while still affirming the importance of emotions, not always conscious, and of relationships (Braithwaite, 1989, 2001: Scheff, 1994, 1997). For instance, Braithwaite's theory of reintegrative shaming, developed and refined since its original formulation in 1989, emphasises the centrality of the emotion of shame, actual or anticipated, in social life, and in particular in securing conformity with social norms and helping offenders to acknowledge the harm they have done and the hurt they have caused, so that they can be re-accepted into communities of care and interdependence. The work on shame of Scheff (1994, 1997) and Retzinger (1991), developed in the different context of understanding conflict and violence, is, as I have argued elsewhere (Smith, 2006), important not only for understanding the roots of violence but for suggesting ways violence and hostility in which might be reduced.

These developments in criminology are in turn compatible with recent research on 'what works' in probation. This has stressed the importance of the quality of the individual relationships offenders have with their probation officers, and of their emotional content (Rex, 1999). Positive relationships, in which the officer shows commitment and concern, and responds warmly to the offender's positive achievements, while being prepared to be directive and authoritative, are more likely to encourage desistance from offending than relationships that are cold, perfunctory, or preoccupied with the enforcement of legal requirements. A focus on desistance, and on the positive characteristics of offenders who succeed in stopping offending, appears in much of this recent work. Farrall (2002), for example, found that 'social capital', mainly in the form of employment and supportive family relationships, was important in achieving desistance, along with motivation on the offender's part. He did not identify elements of probation supervision that may have been important in fostering desistance, but the implications of his analysis for helpful practice are clear enough: officers should focus on strengths, not only on failings and risks, and look beyond the individual offender to his or her social circumstances and relationships. Maruna (2000) stressed the importance of emotions in the process of desistance, or failure to desist: offenders who were able to stop offending were motivated by hope, optimism, and confidence, and were able to conceive of themselves in essentially positive terms, as active agents rather than as doomed creatures of unfortunate circumstances. Maruna (see also Maruna et al., 2004) argued that authority figures such as probation officers could be important in supporting offenders on this path towards 'redemption', and in valuing their positive achievements.

McNeill (2003, 2004, 2006; see also McNeill et al., 2005) has argued (from a Scottish perspective, which may provide a more supportive setting for his arguments 
than exists south of the border) that a 'desistance paradigm' (McNeill, 2006; cf. Bottoms and McWilliams, 1979) for probation practice would entail a revival of old concerns of social work with offenders, such as the quality of the individual relationship, individualised plans for change, and attention to the offender's practical needs. McNeill et al. (2005: 2), writing of key skills for practice in a Scottish Executive publication (which suggests they have a chance gaining an influential readership), describe how a preoccupation with cognitive-behavioural groupwork programmes has marginalised 'more traditional concerns in social work with offenders around the quality of relationships involved in supporting change processes'. They note that recent reviews of 'what works' have begun to include among the factors making for constructive change the exercise of professional discretion by the worker, so that the approach to supervision is appropriate for the offender's needs, interests, and capacities, and the importance of interpersonal and relational skills. This focus on the individual relationship, which McNeill et al. (2005) describe as 'belated' (in terms of research on effectiveness), is, they note, supported by much older research on psychotherapy (Truax and Carkhuff, 1967), which found that the kind of person the worker is, or comes across as being, is more important for therapeutic success or failure than the theories and methods he or she employs. Accurate empathy, respect, warmth and genuineness remain crucial for success, allowing a relationship of mutual respect to develop, in which worker and client form a 'working alliance' to support 'narrative reconstruction' by the offender, from a narrative of victimhood and failure to one of agency and hope (McNeill et al., $2005^{11}$ ). One might then add to Bottoms' (2001) reasons for compliance with supervision (coercion or constraint, habit, self-interest and a sense of moral obligation) the quality of the relationship with the supervising officer, if he or she becomes someone whom the offender would rather not let down, and whose good opinion the offender values and wishes to keep.

The reconstruction over the past ten years of the probation service (in England and Wales) as something other than a social work agency entails the risk of forgetting what may be of positive value in the history of probation practice, as well as what is best treated as an example of what to avoid. This paper has argued that for all its evident limitations and its sometimes hard-to-defend rationalisations, the psychoanalytical orientation of the probation service from (roughly) the mid-1950s to the early 1970s contains lessons that remain valuable in thinking about what constitutes good practice. This has recently, if indirectly, been recognised in criminological research, especially work on criminal careers and desistance, and a parallel development in research on effectiveness has similarly rediscovered the importance of relationships between workers and clients that can accommodate the richness and contradictory complexity of clients' experiences. At a time when the probation service is in the unaccustomed and unwelcome position of being the target of hostile criticism from politicians and the press over failures to 'manage' violent offenders in such a way as to prevent them from committing further serious offences (Travis, 2006), the immediate priorities for policy will no doubt be concerned with further tightening of standards for risk assessment and supervision, and further demands that the service should abide by them. It is unlikely that the question of what

\footnotetext{
${ }^{11}$ In less postmodern language, one might think of this as a process of justified enhancement of selfesteem, or in Scheff's $(1994,1997)$ terms, a move from a state of shame to a state of pride.
} 
are the components of a helpful and supportive supervisory relationship will feature prominently in this scrutiny of the service and its work. But it ought to. 


\section{References}

Ackerman, N.W. (1966) Treating the Troubled Family. New York: Basic Books.

Becker, H.S. (1963) Outsiders. New York: Free Press.

Bennett, T. (2000) Drugs and Crime: The Results of the Second Developmental Stage of the NEW-ADAM Programme (Home Office Research Study 205). London: Home Office.

Bottoms, A.E. (2001) 'Compliance and community penalties', in A.E. Bottoms, L. Gelsthorpe and S. Rex (eds.) Community Penalties: Change and Challenges. Cullompton: Willan.

Bottoms, A.E. and McWilliams, W. (1979) 'A non-treatment paradigm for probation practice’, British Journal of Social Work 9 (2): 159-202.

Braithwaite, J. (1989) Crime, Shame and Reintegration. Cambridge: Cambridge University Press.

Braithwaite, J. (2001) Restorative Justice and Responsive Regulation. Oxford: Oxford University Press.

Caudell, N.L. (1965) 'Conflict, authority and the probation officer', Case Conference 11 (10): 318-21.

Christie, N. (1997) 'Four blocks against insight: notes on the oversocialization of criminologists’, Theoretical Criminology 1 (1): 13-23.

Cohen, P. (1972) 'Subcultural conflict and working class community', Working Papers in Cultural Studies 2 (Spring): 5-51.

Drakeford, M. and Vanstone, M. (eds.) (1996) Beyond Offending Behaviour. Aldershot: Arena.

Farrall, S. (2002) Rethinking What Works with Offenders: Probation, Social Context and Desistance from Crime. Cullompton: Willan.

Folkard, M.S., Smith, D.E. and Smith, D.D. (1976) IMPACT Vol. II: The Results of the Experiment (Home Office Research Study 36). London: Home Office.

Foren, R. and Bailey, R. (1968) Authority in Social Casework. Oxford: Pergamon Press.

Freud, A. (1937) The Ego and the Mechanisms of Defence. London: Hogarth Press.

Friedlander, K. (1947) The Psychoanalytical Approach to Juvenile Delinquency. London: Kegan Paul, Trench, Tubner. 
Gadd, D. and Farrall, S. (2004) 'Criminal careers, desistance and subjectivity: interpreting men’s narratives of change’, Theoretical Criminology 8 (2): 123-56.

Giddens, A. (1994) Beyond Left and Right: The Future of Radical Politics.

Cambridge: Polity Press.

Glover, E. (1960) The Roots of Crime. London: Imago.

Guthrie, L. and Mattinson, J. (1971) Brief Casework with a Marital Problem. London: Institute of Marital Studies.

Hood-Williams, J. (2001) 'Gender, masculinities and crime: from structures to psyches’, Theoretical Criminology 5 (1): 37-60.

Hunt, A. W. (1964) 'Enforcement in probation casework', British Journal of Criminology 4: 239-52.

Institute of Marital Studies (1962) The Marital Relationship as a Focus for Casework. London: Institute of Marital Studies.

Jefferson, T. (1994) 'Theorising masculine subjectivity', in T. Newburn and E.A. Stanko (eds.) Just Boys Doing Business? Men, Masculinities and Crime. London: Routledge.

Jefferson, T. (2002a) 'For a psychosocial criminology', in K. Carrington and R. Hogg (eds.) The Future of Critical Criminology. Cullompton: Willan.

Jefferson, T. (2002b) 'Subordinating hegemonic masculinity', Theoretical Criminology 6 (1): 63-88.

Jordan, W.J.O. (1968a) 'Preventive casework and the disturbed family', Case Conference 14 (12): 470-73.

Jordan, W.J.O. (1968b) 'The transmission of feelings', Case Conference 15 (8): 298-301.

Jordan, W. (1970) Client-Worker Transactions. London: Routledge and Kegan Paul. Jordan, W. (1972) The Social Worker in Family Situations. London: Routledge and Kegan Paul.

Katz, J. (1988) Seductions of Crime. New York: Basic Books.

Keat, R. (1981) The Politics of Social Theory: Habermas, Freud and the Critique of Positivism. Oxford: Basil Blackwell.

‘Lady Almoner’ (1960) ‘Outside in’, Case Conference 7 (2): 35-38.

Laing, R.D. (1965) The Divided Self (paperback edition). Harmondsworth: Penguin. 
Laing, R.D. and Esterson, A. (1964) Sanity, Madness and the Family. London: Tavistock.

Martinez-Brawley, E.E. and Zorita, P. M-B. (1998) 'At the edge of the frame: beyond science and art in social work', British Journal of Social Work 28 (2): 197212.

Martinson, R. (1974) 'What works? Questions and answers about prison reform', The Public Interest 35: 22-54.

Maruna, S. (2000) Making Good. Washington, DC: American Psychological Association.

Maruna, S., Porter, L. and Carvalho, I. (2004) 'The Liverpool Desistance Study and probation practice: opening the dialogue’, Probation Journal 51 (3): 221-32.

Matza, D. (1964) Delinquency and Drift. New York: Wiley.

Mayer, J. and Timms, N. (1970) The Client Speaks. London: Routledge and Kegan Paul.

McNeill, F. (2003) 'Desistance-focused probation practice', in W.H. Chui and M. Nellis (eds.) Moving Probation Forward: Evidence, Arguments and Practice. Harlow: Pearson Longman.

McNeill, F . (2004) 'Supporting desistance in probation practice: a response to Maruna, Porter and Carvalho’, Probation Journal 51 (3): 241-7.

McNeill, F. (2006) 'A desistance paradigm for offender management', Criminology and Criminal Justice, 6 (1): 39-62.

McNeill, F., Batchelor, S., Burnett, R. and Knox, J. (2005) $21^{\text {st }}$ Century Social Work. Reducing Re-offending: Key Practice Skills. Edinburgh: Scottish Executive.

McWhinnie, A. (1956) 'Out of wedlock’, Case Conference 3 (1): 20-22.

Messerschmidt, J.W. (1993) Masculinities and Crime. Lanham, MD: Rowman and Littlechild.

Newton, G. (1958) 'Recent developments in probation’, Case Conference 4 (8): 21926.

Parkinson, G. (1970) 'I give them money’, New Society (5 February): 220-21.

Pepinsky, H.E. (1995) A Peacemaking Primer. At http://www.soci.niu.edu critcrim/pepinsky/hal.primer.

Pincus, L. (1973) (ed.) Marriage: Studies in Emotional Conflict and Growth. London: Institute of Marital Studies. 
Raynor, P. and Robinson, G. (2005) Rehabilitation, Crime and Justice. Basingstoke: Palgrave Macmillan.

Rees, S. and Burke, T. (1966) 'Probation and penal policy’, Case Conference 13 (8): 287-91.

Retzinger, S.M. (1991) Violent Emotions: Shame and Rage in Marital Quarrels. London: Sage.

Rex, S. (1999) 'Desistance from offending: experiences of probation', Howard Journal of Criminal Justice 36 (4): 366-83.

Sampson, R.J. and Laub, J.H. (1993) Crime in the Making: Pathways and Turning Points through Life. London: Harvard University Press.

Satir, V. (1967) Conjoint Family Therapy. Palo Alto, CA: Science and Behavior Books.

Scheff, T.J. (1994) Bloody Revenge: Emotions, Nationalism and War. Boulder, CO: Westview Press.

Scheff, T.J. (1997) Emotions, the Social Bond and Human Reality: Part/Whole Analysis. Cambridge: Cambridge University Press.

Shaw, M. (1974) Social Work in Prison (Home Office Research Study 22). London: Home Office.

Sigal, C. (2005a) Zone of the Interior. Hebden Bridge: Pomona.

Sigal, C. (2005b) ‘A trip to the far side of madness', Guardian Review, 3 December.

Smith, D. (2006) 'What might work with racially motivated offenders?', in S. Lewis, P. Raynor, D. Smith and A. Wardak (eds.) Race and Probation. Cullompton: Willan.

Travis, A. (2006) 'There’s no ignoring probation’s problems’, Society Guardian, 29 March.

Truax, C.B. and Carkhuff, R.R. (1967) Towards Effective Counselling and Psychotherapy. Chicago: Aldine.

Waldron, F.E. (1957) 'The acceptance of dependency in social casework', Case Conference 4 (6): 155-63.

Walrond-Skinner, S. (1976) Family Therapy: The Treatment of Natural Systems. London: Routledge and Kegan Paul.

Vanstone, M. (2004) Supervising Offenders in the Community: A History of Probation Theory and Practice. Aldershot: Ashgate. 
Winnicott, C. (1962) 'Casework and agency function', Case Conference 8 (7): 17884.

Winnicott, D.W. (1958) Collected Papers: Through Paediatrics to Psycho-Analysis. London: Tavistock. 